\title{
Effect of Different Chemicals on Growth and Yield of Rainfed Sorghum
}

\author{
Kalaiyarasan, C¹ , N.Indianraj ${ }^{1}$, K.Suseendran ${ }^{1}$, M.V.Sriramachandrasekharan ${ }^{2}$, S.Jawahar ${ }^{1}$ and $^{1}$ \\ S. Madhavan ${ }^{3}$ \\ ${ }^{1}$ Department of Agronomy, ${ }^{2}$ Department of Soil Science and Agricultural Chemistry, ${ }^{3}$ Department of \\ Horticulture, Faculty of Agriculture, \\ Annamalai University, \\ Annamalai Nagar - 608 002, Tamil Nadu, India. \\ *Corresponding author: email id: kalai77.agri@gmail.com
}

\begin{abstract}
Field Experiment was conducted during June-September-2018 with an objective to enhance growth and yield of rainfed Sorghum thorough foliar fertilization. The experiment was laid out in randomized block design with seven treatments and replicated thrice. The treatment details includes, $\mathrm{T}_{1}-$ Control (Farmer practice), $\mathrm{T}_{2}-$ Full RDF, $\mathrm{T}_{3}-50 \%$ RDF and foliar spraying of "Revive plus" @ $2 \mathrm{~g}$ litre $^{-1}$ twice at 25 and 50 DAS, $\mathrm{T}_{4}-50 \%$ RDF and foliar spraying of "Revive plus" @ 3g litre ${ }^{-1}$ twice at 25 and 50 DAS, $\mathrm{T}_{5}$ - $50 \% \mathrm{RDF}$ and foliar spraying of " $1 \% \mathrm{KCl}$ " twice at 25 and $50 \mathrm{DAS}, \mathrm{T}_{6}-50 \% \mathrm{RDF}$ and foliar spraying of "100ppm Salicylic acid" twice at 25 and 50 DAS, T $-50 \%$ RDF and foliar spraying of "Orthosilicic acid"@2ml litre ${ }^{-1}$ twice at 25 and 50 DAS. The results of the experiments revealed that foliar application of different chemicals significantly influenced the growth and yield attributes and yield. Among the various treatments tried, T - "Revive plus" @ 3g litre ${ }^{-1}$ twice at 25 and 50 DAS recorded maximum values for growth and yield attributes viz., plant height, LAI,DMP, root length and chlorophyll content and yield attributes viz., number of earheads plant ${ }^{-1}$, number of grains earhead ${ }^{-1}$, test weight, seed yield and stover yield and harvest index. The lowest values for growth and yield attributes and yield were recorded in $\mathrm{T}_{1}-$ Control treatment.
\end{abstract}

DOI: $10.7176 / \mathrm{JSTR} / 5-11-02$

\section{Introduction:}

The term rainfed agriculture is used to describe farming practices that solely depend on rainfall for water. It provides much of the food consumed by poor communities in developing countries. Rainfed crop cover more than $80 \%$ of global cropped area and account for $60-70 \%$ of global crop production, but production is frequently limited by drought and soil moisture stress (Wood et al., 2000). In India around 65-70\% of cultivated lands coming under rainfed drylands and they contributing about $45 \%$ of nations food grain production. Most of the crops belongs to millets (>95\%), oilseeds (90\%) and pulses 90-95\% are cultivated on these lands with low productivity. The reasons attributed to low productivity may be inadequate rainfall, poor soil fertility, occurrence of dry spells drought during cropping season, high temperature, more PET than rainfall etc.,. Of these drought at critical period crops season drastically reduces the crop yield. The effect of water stress was found to decrease significantly in photosynthetic rate (Hejank, 2003) transpiration rate (Gupta et al., 2003 ) chlorophyll stability index stomata conductance and relative water content (Gupta et al., 2003). Crops such as millet, foxtail, sorghum and cowpea are also grown in the arid and semi-arid areas affected by drought stress at the reproductive stage (Emam and Zavorakh, 2004). The All India coordinated Research Project for Dryland Agriculture (AICRPDA) in association with state Agricultural universities, Technical Universities and Research Institutes of Indian council of Agricultural Research have developed location-specific rainfed technologies to cope with different drought situations. The key technologies for drought mitigation are in situ moisture conversation, rainwater harvesting and recycling, resilient crops and cropping systems including contingency crop plant, foliar spraying, integrated farming system etc., (Srinivasa Rao et al., 2014). Among these dryland technologies foliar spraying of nutrients and anti-transpirants found to be effective in mitigating drought moisture stress during cropping seasons. 


\section{Materials and Methods:}

The Field Experiments were conducted during June-September-2018 at the farmer's field at Kunjaram village in Ulundurpet Taluk of Villupuram District, Tamil Nadu. The experimental site is situated at $11^{\circ} 41^{\prime} 26^{\prime \prime} \mathrm{N}$ latitude, $79^{\circ} 17^{\prime} 30^{\prime \prime} \mathrm{E}$ longitude with an altitude of $66 \mathrm{~m}$ above mean sea level. The texture of the experimental field soil is sandy loam which is low in available nitrogen, high in available phosphorus and high in available potassium content. Sorghum K8 variety was chosen for this study. The experiment consisted of seven treatments and was laid out in Randomized Block Design with three replications. The treatments imposed in the experiment with different chemicals viz., $\mathrm{T}_{1}$ - Control (Farmer's practice), $\mathrm{T}_{2}$ - RDF 40:20:0 Kgs of NPK ha ${ }^{-1}, \mathrm{~T}_{3}-50 \% \mathrm{RDF}$ and foliar spraying of Revive plus @ 2g litre $\mathrm{g}^{-1}$ at $25 \mathrm{DAS}$ and $50 \mathrm{DAS}, \mathrm{T}_{4}-50 \% \mathrm{RDF}$ and foliar spraying of Revive plus @ 3g litre ${ }^{-1}$ at 25 DAS and 50 DAS, $\mathrm{T}_{5}-50 \% \mathrm{RDF}$ and foliar spraying of $1 \% \mathrm{KCl}$ at $25 \mathrm{DAS}$ and $50 \mathrm{DAS}, \mathrm{T}_{6}-50 \% \mathrm{RDF}$ and foliar spraying of 100ppm Salicylic acid at 25 DAS and 50 DAS and $\mathrm{T}_{7}-50 \%$ RDF and foliar spraying of Orthosilicic acid @ 2ml litre ${ }^{-1}$ at 25 DAS and50 DAS. The recommended dose of 40:20:0 kgs of NPK $\mathrm{ha}^{-1}$ for sorghum varieties were applied in the form the urea $(46 \% \mathrm{~N})$, DAP $\left(18 \% \mathrm{~N}\right.$ and $\left.46 \% \mathrm{P}_{2} \mathrm{O}_{5}\right)$ respectively. Fertilizers were applied fully as basal.

\section{RESULTS AND DISCUSSION:}

\section{Growth attributes (Table 1)}

Among the various foliar nutrition, foliar spray of Revive plus @ $3 \mathrm{~g}$ litre ${ }^{-1}\left(\mathrm{~T}_{4}\right)$ registered the higher plant height, LAI, DMP, chlorophyll content and root length of sorghum and it was comparable with foliar spraying of Revive plus @ $2 \mathrm{~g}$ litre $^{-1}\left(\mathrm{~T}_{3}\right)$ but superior to other foliar fertilization. Increased plant height under this treatment might be due to balanced and increased availability of nutrients to the crop due to foliar application of nutrients. The increased chlorophyll content might be due to the fact that of nitrogen is a constituent of chlorophyll molecule which is expected during rapid grain filling leaves. These results are in agreement with the findings of by Reddy et al, (2018). Increased leaf area index and dry matter production might be due to increased availability of nutrients and its uptake by the crop resulted in higher growth attributing characters which reflected in higher yield of sorghum. These results are in close conformity with the findings of Lakhan singh et al, (2017).

Table 1: Effect of foliar fertilization of different chemicals on growth attributes of sorghum

\begin{tabular}{|c|c|c|c|c|c|}
\hline Treatments & $\begin{array}{c}\text { Plant } \\
\text { height }(\mathbf{c m}) \\
\text { At harvest } \\
\text { stage }\end{array}$ & $\begin{array}{c}\text { LAI at } \\
\text { flowering } \\
\text { stage }\end{array}$ & $\begin{array}{c}\text { DMP }\left(\mathrm{Kg} \mathrm{ha}^{-\mathbf{1}}\right) \\
\text { at harvest stage }\end{array}$ & $\begin{array}{c}\text { Chlorophyll } \\
\text { content }\left(\mathbf{m g} \mathbf{g}^{-\mathbf{1}}\right) \\
\text { at flowering } \\
\text { stage }\end{array}$ & $\begin{array}{c}\text { Root length } \\
\mathbf{( \mathbf { c m } ) \text { at }} \\
\text { harvest stage }\end{array}$ \\
\hline $\mathbf{T}_{\mathbf{1}}$ & 171.9 & 2.99 & 12495.6 & 39.45 & 32.1 \\
\hline $\mathbf{T}_{\mathbf{2}}$ & 175.4 & 3.15 & 12607.6 & 40.65 & 33.1 \\
\hline $\mathbf{T}_{\mathbf{3}}$ & 182.8 & 3.40 & 12958.8 & 42.18 & 34.3 \\
\hline $\mathbf{T}_{\mathbf{4}}$ & 184.4 & 3.44 & 13065.4 & 42.50 & 34.5 \\
\hline $\mathbf{T}_{\mathbf{5}}$ & 179.8 & 3.24 & 12824.6 & 41.08 & 33.5 \\
\hline $\mathbf{T}_{\mathbf{6}}$ & 173.2 & 3.09 & 12585.3 & 39.92 & 32.5 \\
\hline $\mathbf{T}_{\mathbf{7}}$ & 180.5 & 3.32 & 12901.9 & 41.53 & 33.8 \\
\hline $\mathbf{S E . d}$ & 2.99 & 0.05 & 345.12 & 0.97 & 0.79 \\
\hline $\mathbf{C D}(\mathbf{p}=\mathbf{0 . 0 5})$ & 6.52 & 0.12 & 751.95 & 2.11 & 1.72 \\
\hline
\end{tabular}

Yield attributes and yield (Table 2)

Among the various foliar nutrition tried, foliar spray of Revive plus @ $3 g \operatorname{litre}^{-1}\left(\mathrm{~T}_{4}\right)$ recorded the maximum number of earhead plant ${ }^{-1}$, number of grains earhead ${ }^{-1}$, test weight, grain yield, stover yield and harvest index for pearlmillet and sorghum. It is comparable with foliar spraying of Revive plus @ $2 \mathrm{~g} \operatorname{litre}^{-1}\left(\mathrm{~T}_{3}\right)$ but superior to other foliar fertilization. The combined fertilizer application through foliar nutrition increased yield attributes and yield of millets might be due to the supplementation of plants with the three major nutrients and micronutrients together and these elements enhancing and including

$10 \mid$ P a g e

www.iiste.org 
most of metabolic processes, $\mathrm{N}$ increased the protein formation, phosphorous in the formation of nucleic acids and energy compounds while potassium affected the water adjustment and carbohydrate transportation. This was in line with the findings of Hussein et al. (2011). Grain yield increased by foliar application of potassium due to improving the enzymes activity in the plant, which leads to easy translocation of photosynthates from leaf to grain in maize. Similar finding was earlier reported by Abid Ali et al. (2016). Application of nutrients influenced the higher growth parameters and improves drymatter accumulation which in turn improves yield parameters. Later this drymatter was translocated to different yield components thereby increases grain yield. This was evidenced through the studies of Shankar et al, (2017) in little millet. The harvest index was increased by the foliar application of nutrients might be due to the nutrients are utilized for increasing the vegetative growth than producing economic yield. The results of present study fall in line with the findings of Lakhan singh et al. (2017) who reported that increased availability of nutrients enhanced growth and yield attributing characters which reflected in higher yield of pearlmillet.

Table 2: Effect of foliar fertilization of different chemicals on yield and yield attributes of sorghum

\begin{tabular}{|c|c|c|c|c|c|c|}
\hline Treatments & $\begin{array}{l}\text { No. of } \\
\text { earheads } \\
\text { plant }^{-1}\end{array}$ & $\begin{array}{l}\text { No. of } \\
\text { grains }_{\text {earhead }^{-1}}\end{array}$ & $\begin{array}{l}\text { Test } \\
\text { weight }(\mathbf{g})\end{array}$ & $\begin{array}{l}\text { Grain } \\
\text { yield }(\mathbf{K g} \\
\left.\text { ha }^{-\mathbf{1}}\right)\end{array}$ & $\begin{array}{l}\text { Stover } \\
\text { yield }(\mathbf{K g} \\
\left.\text { ha }^{-\mathbf{1}}\right)\end{array}$ & $\begin{array}{l}\text { Harvest } \\
\text { index } \\
(\mathbf{1 0 0})\end{array}$ \\
\hline $\mathbf{T}_{\mathbf{1}}$ & 2.2 & 965 & 20.45 & 875.66 & 5759.66 & 13.19 \\
\hline $\mathbf{T}_{\mathbf{2}}$ & 2.4 & 1029 & 20.96 & 1246.33 & 6048.66 & 17.08 \\
\hline $\mathbf{T}_{\mathbf{3}}$ & 3.0 & 1254 & 21.74 & 1431.50 & 6608.66 & 17.80 \\
\hline $\mathbf{T}_{\mathbf{4}}$ & 3.2 & 1288 & 21.88 & 1545.16 & 6765.00 & 18.59 \\
\hline $\mathbf{T}_{\mathbf{5}}$ & 2.6 & 1107 & 21.08 & 1354.00 & 6216.33 & 17.88 \\
\hline $\mathbf{T}_{\mathbf{6}}$ & 2.4 & 1007 & 20.88 & 1203.50 & 5933.33 & 16.86 \\
\hline $\mathbf{T}_{\mathbf{7}}$ & 3.0 & 1182 & 21.59 & 1364.66 & 6427.33 & 17.51 \\
\hline $\mathbf{S E . d}$ & 0.06 & 19.18 & 0.45 & 21.83 & 58.32 & 0.33 \\
\hline $\mathbf{C D}(\mathbf{p}=\mathbf{0 . 0 5})$ & 0.13 & 41.79 & 0.98 & 47.57 & 127.08 & 0.72 \\
\hline
\end{tabular}

\section{REFERENCES:}

Abid Ali., Mozammil Hussain, Hafiz Saqib Habib, Touseef Taj Kiani, Muhammad Abbas Anees and Muhammad Abdul Rahman. 2016. Foliar spray surpasses soil application of potassium for maize production under rainfed conditions. Turk. J. Field crops, 21(1):36-43.

Bhanu Prasad Reddy, S., K.V. Naga Madhuri, Keerthi Venkaish and T. Prathima. 2018. Effect of nitrogen and potassium on yield and quality of pearl millet (Pennisetum glaucum L.). Intl. J. of Agrl. Innovation and Res., 4: 2319 -1473.

Emam, A. and M. Zavareh. 2004. Drought tolerance in plants (Analysis of the physiological and molecular biology) (Translation). University publishing centre. Page. 75.

Gupta, S.K., N.A. Ritchey, A.C. Wilber, C.H. Whitlock, G.G. Gilbson and P.W.J. Stackhouse. 2003. A climatology of surface radiation budget derived from satellite data. J. of climate, 12(8): 26912710.

Hejanak,V. 2003. The effect of drought on production of dry matter in spraying barley (Hordeum vulgare L.). Scientia Agriculturae Bohemica, 34: 121-128. 
Hussain, F., A.U. Malik, M.A. Haji and A.L. Malghani. 2011. Growth and yield response of two cultivars of mungbean (Vigna radiata L.) to different potassium levels. The J. Ani., Plant Sci., 21(3): 622-625.

Lakhan Singh, PK. Sharma, M. Jajoria, P. Deewan and R. Verma. 2017. Effect of Phosphorus and Zinc Application on Growth and Yield Attributes of Pearl millet (Pennisetum glaucum L.) under Rainfed Condition. J. of Pharmacognosy and Phytochem., 6(1): 388-391.

Shankar Charate, M.N. Thimmegowda, B.K. Ramachandrappa and Gangadhar Eswar Rao. 2017. Influence of Nitrogen and Potassium Levels on Plant Water Status, Yield and Economics of Little Millet (Panicum sumatrense) Under Rainfed Condition. Int. J. Curr. Microbiol. App. Sci., 6(12): $150-156$.

Srinivasarao, CH., Rattan Lal, Sumanta Kundu, M.B.B. Prasad Babu, Venkateswarlu, B. and Anil Kumar Singh. 2014. "Soil carbon sequestration in rainfed production systems in the semiarid tropics of India". Science Total Environ., 487: 587-603.

Wood, S., K. Sebastian, S.J. Scherr. 2000. Pilot analysis of Global Ecosystems: Agroecosystems. World resource institute and International food policy research institute, Washington, DC. 